\title{
Correction to: Epidermal stem cells in wound healing and their clinical applications
}

Ronghua Yang ${ }^{1}$, Fengxia Liư ${ }^{2}$ Jingru Wang ${ }^{1}$, Xiaodong Chen ${ }^{1}$, Julin Xie ${ }^{3^{*}}$ and Kun Xiong ${ }^{4^{*}}$

\author{
Correction to: Stem Cell Res Ther (2019) 10:229 \\ https://doi.org/10.1186/s13287-019-1312-z
}

The original article [1] omits an acknowledgement of permission to reproduce the original version of Figure 1 (published in Actas Dermosifiliogr, 2015 [2]) in this article.

The authors wish to note the following in this correction article:

Figure 1 was published with permission of the Publisher. Original source: Pastushenko I, Prieto-Torres L, Gilaberte

Published online: 22 October 2020

References

1. Yang R, Liu F, Wang J, Chen X, Xie J, Xiong K, et al. Epidermal stem cells in wound healing and their clinical applications. Stem Cell Res Ther. 2019;10: $229 \mathrm{https} / / / \mathrm{doi}$. org/10.1186/s13287-019-1312-z.

2. Pastushenko I, Prieto-Torres L, Gilaberte Y, Blanpain C. Skin Stem Cells: At the Frontier Between the Laboratory and Clinical Practice. Part 1: Epidermal Stem Cells. Actas Dermosifiliogr. 2015;106(9):725-32 English, Spanish. https://doi.org/10.1016/j.ad.2015.05.008. Epub 2015 Jul 17. PMID: 26189363. Y, Blanpain C. Skin Stem Cells: At the Frontier Between the Laboratory and Clinical Practice. Part 1: Epidermal Stem Cells. Actas Dermosifiliogr. 2015;106:725-32. @ 2015 Elsevier España, S.L.U. and AEDV. All rights reserved.

\section{Author details}

'Department of Burn Surgery, The First People's Hospital of Foshan, Foshan 528000, China. ${ }^{2}$ Department of Human Anatomy, School of Basic Medical Science, Xinjiang Medical University, Urumqi 830001, China. ${ }^{3}$ Department of Burn Surgery, First Affiliated Hospital of Sun Yat-Sen University, Guangzhou 512100, China. ${ }^{4}$ Department of Anatomy and Neurobiology, School of Basic Medical Science, Morphological Sciences Building, Central South University, 172 Tongzi Po Road, Changsha 410013, Hunan, China.

\footnotetext{
The original article can be found online at https://doi.org/10.1186/s13287019-1312-z.

*Correspondence: sysxiej190@sohu.com; xiongkun2001@163.com

${ }^{3}$ Department of Burn Surgery, First Affiliated Hospital of Sun Yat-Sen University, Guangzhou 512100, China

${ }^{4}$ Department of Anatomy and Neurobiology, School of Basic Medical Science, Morphological Sciences Building, Central South University, 172 Tongzi Po Road, Changsha 410013, Hunan, China

Full list of author information is available at the end of the article
}

(c) The Author(s). 2020 Open Access This article is licensed under a Creative Commons Attribution 4.0 International License, which permits use, sharing, adaptation, distribution and reproduction in any medium or format, as long as you give appropriate credit to the original author(s) and the source, provide a link to the Creative Commons licence, and indicate if changes were made. The images or other third party material in this article are included in the article's Creative Commons licence, unless indicated otherwise in a credit line to the material. If material is not included in the article's Creative Commons licence and your intended use is not permitted by statutory regulation or exceeds the permitted use, you will need to obtain permission directly from the copyright holder. To view a copy of this licence, visit http://creativecommons.org/licenses/by/4.0/ The Creative Commons Public Domain Dedication waiver (http://creativecommons.org/publicdomain/zero/1.0/) applies to the data made available in this article, unless otherwise stated in a credit line to the data. 


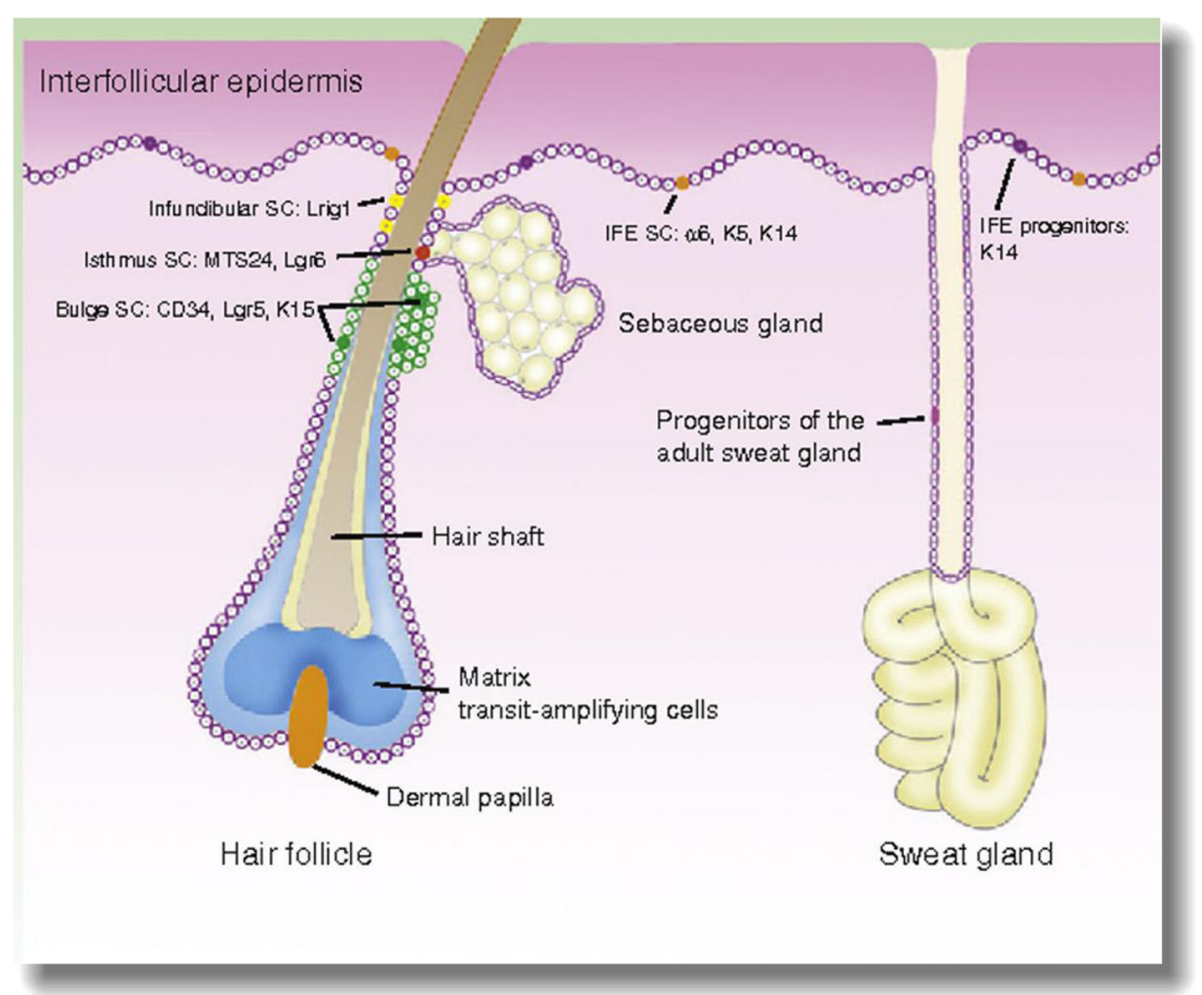

Fig. 1 Illustration of the different populations of EPCs and their specific markers. Figure 1 was published with permission of the Publisher. Original source: Pastushenko I, Prieto-Torres L, Gilaberte Y, Blanpain C. Skin Stem Cells: At the Frontier Between the Laboratory and Clinical Practice. Part 1: Epidermal Stem Cells. Actas Dermosifiliogr. 2015;106:725-32. @ 2015 Elsevier España, S.L.U. and AEDV. All rights reserved 